\title{
Revisit of Six Misconceptions Affected to Business and Economic Management
}

\author{
Dr.Chanchai Petchprapunkul \\ Deputy Department Head, Department of Cooperatives Economics, \\ Faculty of Economics, Kasetsart University, Bangkhen Campus, Bangkok 10900, Thailand
}

\begin{abstract}
This paper proposed the six error concepts that lead to mismanagement in business and economic. Firstly, the concept of the Wealth of Nations (1776) of Adam Smith. Secondly is the misunderstanding among maximizing profit organization, non profit organization, and not for profit organization. Thirdly, cooperatives business organization is the most efficient organization in the term of income distribution. They had distributed their surplus back to their members, because their member is both consumer and owner of the organizations. Thus cooperatives economic will have less dead weight lose. Fourthly is Keynesian's Demand management (1936) and its variation in financial market and labor market. Fifthly, SWOT analysis explanation by Humphrey 1960-70, what wrong is misunderstanding of the change of threat to be opportunity? Lastly is Income distribution in macroeconomic which we will never reach it. An online survey was conduct, 250 questionnaires survey were sent to the sampling and 149 respondents were answer and submit back their questionnaires. The result of the study had confirmed all the issues proposed above.
\end{abstract}

Keywords: Morale sentiment, The Wealth of Nations, Not for profit, SWOT analysis, Demand management Income distribution.

\section{Introduction}

Within the business and economics discipline, there are some errors concepts lead to mismanagement in business and economic organizations. Firstly is the misunderstanding and concentration on wealth and capital accumulation that leads to the wider income gap between the riches and the poor in every country. Secondly is the divergence among maximizing profit organizations, non profit organizations, and not for profit organization. Maximizing profit organization ideology leads to the inefficiency in global natural resource and economic resource consumption. Thirdly is the dead weight lost from the total economic surplus in the society due to the mismanagement among government, firm and consumer. Trade off between consumer surplus and producer surplus under the capitalism concept. Forth is the mis-adoption of the SWOT analysis to explain the firm strategic management. Fifth is the Keynesian Demand Management which created error and variation of financial crisis. The sixth is the worse income distribution in every country in the world.

\section{Literature review}

The six misconceptions had shown out many disadvantages and side effects to the business and economic management. This part will elaborate those six ambiguous concepts and propose the correction of them.

\subsection{Morale Sentiment and the Wealth of Nations (Adam Smith 1759, 1776)}

Almost people in the world were informed by Adam Smith in 1776 that to make countries got prosperity, government of that country has to encourage wealth and capital accumulation. Every country tried to gain more benefit and advantages from the term of trade they can seek, without ethic or any fair conduct. This had made government and people in every country selfish and greedy to earn more and more benefit, both private sector and even government officer in public sector. In deed, Adam Smith had written a manuscript of "the Morale Sentiment" in $1759^{[1]}$, this work was about those standards of ethical conduct that hold society together, but it was not gained any interests from people and Adam Smith had burnt it out in 1788. Therefore, people those mostly turn to pay attention on "An Inquiry into the Nature and Causes of Wealth of Nation" had faced many economic problems, selfish, over demand, and over consumption, etc. 


\subsection{Maximizing profit, Non profit, and Not for profit organization}

Maximize profit is a concept of the firms under the mainstream economic system. It explains the profit from the business of the producer under the free trade. Microeconomic discipline proposed that if the firm produced or pricing their product at the point of intersection between marginal cost and marginal revenue or at the point of $\mathrm{MC}=\mathrm{MR}$ or point $\mathrm{A}$ in Figure $1^{[2],[3]}$, producer will get the highest profit from the distance of $\mathrm{P}_{1}$ to $\mathrm{P}_{4}$. Since the distance from point of origin (o) to $\mathrm{P}_{1}$ is the price of product producer gained, distance from o to $\mathrm{P}_{4}$ is total cost, thus the distance of $\mathrm{P}_{1}$ to $\mathrm{P}_{4}$ will be profit and this range is the maximum amount of profit or maximizing profit.

But, indeed if the firm have their higher and higher amount of total cost over $\mathrm{P}_{4}$, the amount of profit will be decreased continuously, distance between $\mathrm{P}_{1}$ and $\mathrm{P}_{4}$ will narrow and narrow. Therefore, we can not say this situation producer will have their max profit, it is only max revenue.

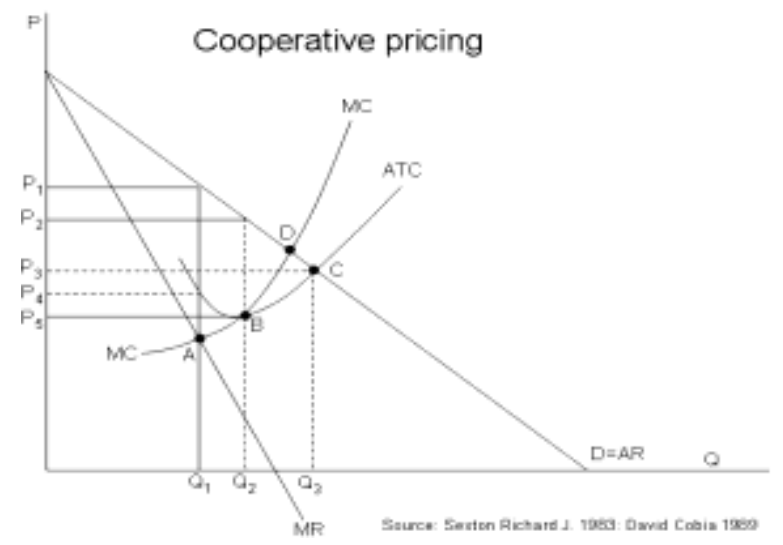

Fig. 1: Pricing among producers under free trade when producers have their market power and the cooperative pricing

The upper case imply that if the producers have less efficiency in their production stages and the total cost is not stable, total cost will get higher and higher to force the amount of profit will get smaller and smaller. From the above assumption, most of business organizations are concentrated on maximizing profit, to gain all benefit from consumer and society. If the total cost of firms under free trade is higher and higher, we can see that burden is put on people or population of a country not the producer themselves. While cooperatives business organizations will pricing at the point $\mathrm{C}$ which is the break-even point. At this point the cooperatives enterprise can distribute their service to people who are their members more than the capitalism did. But, non profit organization is providing free service. They had received the donation from public or government, such as public hospital or public schools.

\subsection{Consumer surplus, Producer surplus, and Economic surplus}

Microeconomics discipline had provided the term consumer surplus, producer surplus and economic surplus.

- Consumer surplus

Consumer surplus is what consumer or buyer bought a good with the willingness to pay more for their purchase than the price they actually pay. Consumer surplus is the price a consumer actually pays is less than they are prepared to pay. The demand curve indicates what price consumers are prepared to pay for hypothetical quantity of a good, based on their expectation of their private benefit/value/utility they got.

- Producer surplus

Producer surplus is the additional private benefit to producer in term of profit, gained what the price they received in the market is more than the minimum they would be prepared to supply for.

In the cooperatives enterprise, consumer surplus and producer surplus blend together is the total economic surplus of a nation. Thus, if their have some causes to reduce the area of total surplus, we call that area the deadweight lost.

- Economic surplus

Cooperatives enterprise had less the deadweight loss compared to the general mainstream economy. Cooperatives enterprise themselves can not claimed that they are the organization that want no profit because the 
cooperatives had changed to call the profit as surplus, as elaborate in Figure 2. Suppose the economy had limited of production at only Qm level, the dead weight loss will be the area of D+E, but if thy economy had the production level at Qc, the price level of products will be at only $\mathrm{Pc}$ and Qc. The consumer surplus will be $\mathrm{A}+\mathrm{B}+\mathrm{D}$, the producer surplus will be only $\mathrm{C}+\mathrm{E}$ and $\mathrm{A}+\mathrm{B}+\mathrm{C}+\mathrm{D}+\mathrm{E}$ are economic surplus.

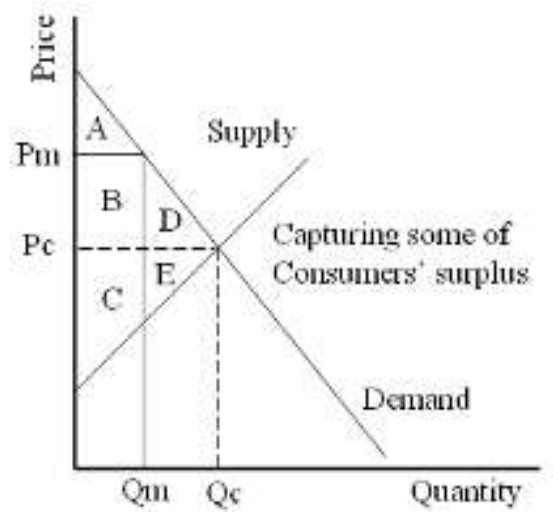

Fig. 2: Consumer surplus, Producer surplus and Economic surplus

\subsection{SWOT analysis}

Literatures still haven't proposed whom was the first academician proposed the concept of SWOT analysis. Anyway, Harvard business school claim that SWOT analysis is credited to George Albert Smith Jr. and C Roland Christiensen during the early 1950s. Professor Albert Humphrey (1960s-1970s) ${ }^{[4]}$ from the University of Stanford had conducted a research project in the 1960s-1970s. Humphrey led a research project which ultimately developed his Team Action Model (TAM) which is a management concept that enables group of executives to manage change. The third work related to SWOT analysis is the Ansoff's matrix frame by Igor Ansoff ${ }^{[5]}$ (1987). SWOT analysis mostly related to the corporate strategy of the firm.

Even there were many scholars had elaborated about the concept of SWOT analysis, but many people still misunderstanding and misleading about the change of "Threat" to be "Opportunity" which is will can not be happen. The following figure proposed how to use and explain the SWOT analysis correctly.

According to Figure 3, SWOT analysis is using to explain the three levels of environments, the first level is country level, the second is industry level, and the third is firm level. A business organization have to evaluate their own firm situation under the two external environment, they are general environment at the country level and the competitive environment at the industry level. These two levels of forces will finally identify the business opportunity or business threat to the firm. Thus, we can only explore them and identify that they are create advantages available in that country or that industry or not. If they provided advantages to the country or the industry, our firm will can be also taken that benefits from such industry or not. We can not change threat to be opportunity. Because those all threats or opportunities are the external forces, we can not change bad forces to be good forces in a country or within an industry level.

Thus, we can explore that any firms when we assess by a graph diagram, the Y exist will assess the external environment which are the "Opportunity: O" or "Threat: $\mathrm{T}$ " while the $\mathrm{X}$ exist must evaluate the internal environment in a firm, or "Strength: S" and "Weakness: W" of that firm. On the Y exist, the nearer to the origin point or range of 1 must be assessed "threat", and the range of 2 must be assessed "opportunity". On the X exist, the nearer to the origin point or range of 3 must be assessed "weakness", and the range of 4 must be assessed "strength", as elaborated in Figure 3.1 and 3.2 


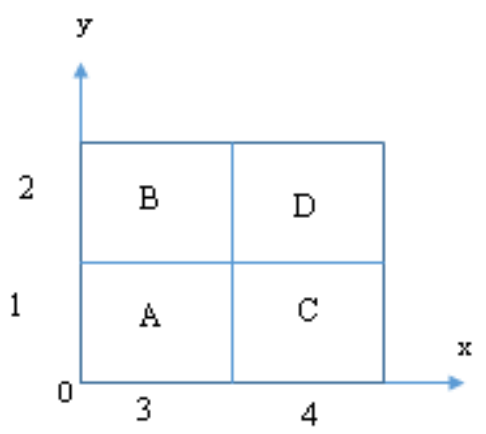

Fig. 3.1 SWOT analysis

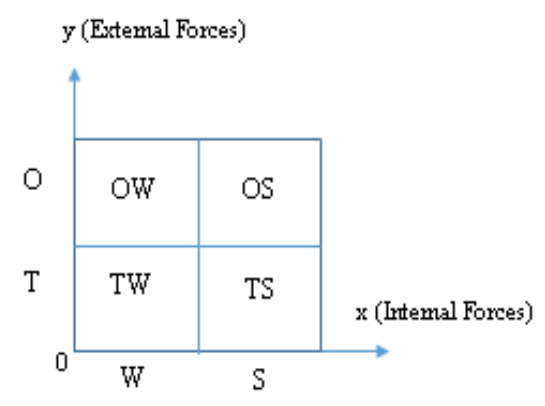

Fig. 3.2 SWOT analysis

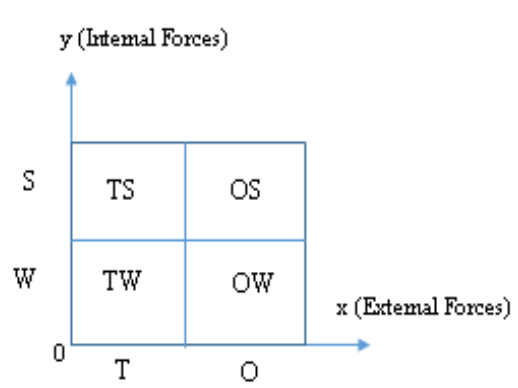

Fig. 3.3 SWOT analysis

The result of four cells belong to each area will identify that, cell "A" must be contained the firm that pertain much of weakness and the external environment pursue threat more than opportunity to the firm. This is the worse case. Cell A area is denoted as "T-W" situation. Cell B must be contained the firm that pertain much of weakness but the external environment pursue opportunity more than threat to the firm. Cell B area is denoted as "O-W" situation. Cell "C" must be contained the firm that pertain much of strength while the external environment pursue threat more than opportunity to the firm. Cell $\mathrm{C}$ area is denoted as "T-S" situation. Cell "D" must be contained the firm that pertain much of strength with the external environment pursue opportunity more than threat to the firm. Cell D area is denoted as "O-S" situation. According to the graphical method of all coordinates, we will seen that most of the firms might would be staying at the cell $\mathrm{D}$ along the regression line between coordinate $\mathrm{E}$ and $\mathrm{F}$ or the 45 degree line that upward sloping along the right hand side.

This model proposed that most of the firm in any industries have to develop their own firm's capability to be enough to compete with others in the same industry for their future business opportunity. In the opposite way, if any firms had make a mistake to use the $\mathrm{X}$ exist represent the external environment, the $\mathrm{Y}$ exist represent or assess the internal environment, we will seen that cell $\mathrm{B}$ and cell $\mathrm{C}$ will interchange together, but cell $\mathrm{A}$ and $\mathrm{D}$ will not change anything, as elaborated in Figure 3.3, we still can not change threat to be opportunity.

\subsection{Keynesian Demand Management (1936)}

According to the great depression in the U.S.A. in 1929, seven years later, John Maynard Keynes proposed to the U.S.A. government to inject more government expenditure into the economy. This government expenditure will induce the aggregate expenditure of the economy to lead to the increase of aggregate consumption and GDP growth. Anyway, every country always used this policy to inject the government expenditure. This had leads to the increase of the excess demand for money in the demand side of the economy and lead to financial market downturn. In the supply side, the excess supply of the production function had lead to the excess supply of the labour in the labour market and lead to the excess supply of labour problems.

\subsection{Income Distribution}

In come distribution is an economic phenomenon in both the developed countries and developing countries. We can see many countries face the problem of the economic gap between the rich and the poor problems. For example, the conflict between the group of red shirts and the yellow shirts in Thailand which still have been the most un-solve problem.

\section{Study method}

250 survey questionnaires were sent via the email address of the sampling, to collect how the consensus ideas from the undergraduate students in the field of business and economics look like, only 149 of sampling had fill out questionnaires and submit it back via the online survey. Data from the respondents were edited and calculated to find the statistics from the information that will identify how the respondents had their viewpoint on those six mis-concepts related to business and economics. 


\subsection{Descriptive statistics}

Respondents are the third and forth year students at the undergraduate level in the field of cooperative economics, Department of Cooperatives Economics, Faculty of Economics, Kasetsart University, Bangkean campus, Bangkok, Thailand. $56.4 \%$ of them are female and $43.6 \%$ are male. All of them are at the age around 22-23 years old as elaborated in Table 1 .

TABLE I: The Characteristic of respondents

\begin{tabular}{llll}
\hline \hline Gender & 65 males & 84 Females & Total 149 \\
\hline Degree & Bachelor & Bachelor & Bachelor \\
Age & Around 22-23 & Around 22-23 & Around 22-23 \\
\hline \hline
\end{tabular}

\subsection{Inference statistics}

From the primary survey, most of the respondent agreed with the researcher viewpoint about the different about the advantage and disadvantage of capitalism economics, institutionalism economics, and the cooperatives economics, as the percentage below among the ten items of questions. Score $1=$ strongly disagree, score 2 is disagree, score 3 is mean between disagree and agree, score 4 is agree, score 5 is strongly agree.

\begin{tabular}{|c|c|c|c|c|c|c|}
\hline & & \multicolumn{5}{|c|}{$\%$ of answer on each scale } \\
\hline & Issues & 1 & 2 & 3 & 4 & 5 \\
\hline 1.1 & $\begin{array}{l}\text { How much the degree that you known about the Morale Sentiment of Adam } \\
\text { Smith (1759)? }\end{array}$ & .7 & 2.7 & 30.9 & 34.2 & 31.5 \\
\hline 1.2 & $\begin{array}{l}\text { How much the degree you agreed that An Inquiry into the Nature and } \\
\text { Causes of the Wealth of Nations by Adam Smith (1776) had created the } \\
\text { selfish for capital and excess consumption of economic resource and natural } \\
\text { resource? }\end{array}$ & 2.0 & 6.7 & 27.5 & 38.3 & 25.5 \\
\hline 2.1 & $\begin{array}{l}\text { How much the degree you agreed that "Maximize Profit" is the goal of } \\
\text { capitalism? }\end{array}$ & 0.7 & 1.3 & 25.5 & 32.2 & 40.3 \\
\hline 2.2 & $\begin{array}{l}\text { How much the degree you agreed that "Non Profit Organization" received } \\
\text { the donation from government or public, such as public hospitals or public } \\
\text { schools? }\end{array}$ & 6.0 & 7.4 & 22.1 & 41.6 & 22.8 \\
\hline 2.3 & $\begin{array}{l}\text { How much the degree you agreed that Cooperatives is a kind of Not for } \\
\text { profit organization because they distribute almost their surplus to their } \\
\text { member in the form of patronage refund and dividend pay out? }\end{array}$ & 4.0 & 5.4 & 22.8 & 34.2 & 33.6 \\
\hline 3.1 & $\begin{array}{l}\text { How much the degree you agreed that in cooperatives organization, } \\
\text { consumer surplus and producer surplus is belonging to the same person or } \\
\text { member of the cooperatives. Thus cooperatives organization has no need to } \\
\text { try to acquire and compete for consumer and producer surplus? }\end{array}$ & 1.3 & 5.4 & 29.5 & 45.6 & 18.1 \\
\hline 4.1 & $\begin{array}{l}\text { How much the degree you agreed that, in the graphical method to elaborate } \\
\text { the SWOT analysis, it consists of external forces and internal forces, Y exist } \\
\text { is to represent for the external force in the environment, opportunity and } \\
\text { threat? X exist is to represent for the internal force in the environment, } \\
\text { strength and weakness? }\end{array}$ & 0.7 & 0.7 & 25.5 & 36.9 & 36.2 \\
\hline 4.2 & $\begin{array}{l}\text { Are you agreed that under the SWOT analysis, we can change "threat" to be } \\
\text { "opportunity" }\end{array}$ & 1.3 & 4.7 & 18.8 & 38.9 & 36.2 \\
\hline 5 & $\begin{array}{l}\text { How much you agreed that the Demand management of Keynesian, if we } \\
\text { used it at the wrong situation, it will create the disadvantage to the economy, } \\
\text { such as financial crisis. }\end{array}$ & 0.7 & 2.7 & 32.9 & 38.3 & 25.5 \\
\hline 6 & $\begin{array}{l}\text { How much you agreed that income distribution in every country still has no } \\
\text { succeed. }\end{array}$ & 3.4 & 3.4 & 28.9 & 32.9 & 31.5 \\
\hline & Grand total & 2.08 & 4.04 & 26.22 & 37.31 & 30.12 \\
\hline
\end{tabular}

\section{Result of the study}

Over $93 \%$ of students are agreed with the theme of research questions in this study. $30.12 \%$ of them are strongly agree with the questions 37.31 of them are agreed with the research questions, and 26.22 are at the fair or medium level agree with the research questions. Only $6.12 \%$ not agree with the research questions.

The author can implied that, students who are studying in the major of cooperatives economics had pertain the high level of understanding of the advantages of the Institutional Economics and Cooperative Economics, and also known about the disadvantage of the Capitalism Economics. Therefore, the subjects of Managerial 
Economics for the Cooperatives Enterprise and The Institutional Economics for the Cooperatives are very valuable to students in the area of Economics to reduce the selfish of people in our economy.

\section{Suggestion and recommendation}

The author would like to suggest that in order to make our society get sustainable economic development, firm have to manage their business performance as fair as possible and as optimize as they can, not as much as possible.

\section{Acknowledgements}

The author would like to gratefully thankful to the third and forth year students of the Department of Cooperatives Economics, Faculty of Economics, Kasetsart University, Bangkok 10900, who had kindly fill out the questionnaires survey of this research.

\section{References}

[1] Mark Blank 1986, "Great Economists before Keynes". An Introduction to the Lives and Works of One Hundred Great Economists of the Past. Wheatsheaf books

[2] Sexton Richard J 1983, "Cooperatives and the Forces Shaping Agricultural Marketing", American Agricultural Economics Association.

[3] Cobia D. 1989, "Cooperatives in Agriculture", New Jersey:

[4] Albert Humphrey 1960, "SWOT analysis", History of SWOT analysis: http://www.marketingteacher.com

[5] Ansoff I. H. 1987, "Corporate Strategy", An analytic Approach to Business Policy for Growth and Expansion, New York, McGraw Hill 